\title{
Carbon Capture Potential in Lime Modified Kaolin Clay
}

\author{
Amos Yala Iorliam, $\mathrm{PhD}^{* 1}$ Moses Msuega UFe, M.Sc ${ }^{* 2}$ Benedict Anum, M.Eng. ${ }^{* 3}$ \\ ${ }^{*}$ Department of Civil Engineering, Federal University of Agriculture Makurdi, Nigeria. \\ ${ }^{1}$ Corresponding author’s E-mail address: amosyalas2007@yahoo.com, iorliam.yala@uam.edu.ng
}

\begin{abstract}
This research presents the potential of combined carbon capture alongside compressive strength improvement in carbonated lime treated kaolin clay, and determines the suitability of the strength improvement for application to capping layer in road pavement. Using combined modification and carbonation treatment at controlled air voids, $4.7 \%$ $10 \%$ calcium carbonate was determined in kaolin treated with $4-8 \%$ calcium hydroxide contents in samples at $10 \%$ air voids. Strength increase was achieved in carbonated lime-treated kaolin from $170 \mathrm{kPa}$ to $280 \mathrm{kPa}$ compared with soaked non-carbonated lime treated kaolin, which shows significant increase of approximately $65 \%$. This method of combined modification and carbonation in lime treated clay has the potential to capture carbon alongside improving the strength of the weak kaolin, and could be effectively used for combined carbon capture and road pavement functions.
\end{abstract}

\section{Keywords - Carbon capture, Strength improvement, Carbonation, Modification, Lime treatment}

\section{INTRODUCTION}

The nature of clay poses problem to geotechnical engineering practice due to its properties such as low strength, high plasticity, and poor workability. Lime has been used for treatment of clay due to its potential to improve plasticity, strength and workability of clay for construction purposes [1], [2]. However, the production of lime itself produces additional carbon dioxide $\left(\mathrm{CO}_{2}\right)$ emissions [3]. Mitigating the effects of increase in $\mathrm{CO}_{2}$ and other greenhouse gases (GHGs) constitutes another concern to geotechnical engineering. This is because the effects of these increases is causing the Earth to become warmer [4]. The consequences on environment include increases in risk of flooding and subsequent people displacement, threat to food security, risk of increase in heatrelated illness and disease, threat to wildlife and risks of intense storm [5]. Climate change also potentially poses a threat to the sustainability of engineering infrastructures and in particular soil based constructed infrastructures such as embankments, and pavements [6].

Previous researchers [7], [ 8] have conducted studies on carbon capture in soils and have reported that soils which are rich in calcium or magnesium silicate minerals can store atmospheric $\mathrm{CO}_{2}$ as calcium carbonate $\left(\mathrm{CaCO}_{3}\right)$. However, combined solution of carbon capture and strength improvement in soil have not been attempted. The combined modification and carbonation method for carbon capture alongside soil improvement offers one novel solution to this need.

\section{I.A. Lime Modification Concept}

Lime modification, which is the addition of calcium hydroxide $\left(\mathrm{Ca}(\mathrm{OH})_{2}\right)$ to clay, has been successfully used for the treatment of soft clay for construction purposes, mainly due to the reduction in plasticity of the clay as a result of cation exchange [2]. Lime modification takes place at short term, thus offering the advantage to reduce delays to construction during wet weather [2]. In the current study, lime modification can be defined as the short term reaction that occurs in lime treated soil, resulting in reduction in plasticity and improvement of workability [9].

\section{I.B. Carbon Capture}

The increase in atmospheric $\mathrm{CO}_{2}$ concentration by $40 \%$ since the start of the industrial revolution (since 1750) is believed to be linked to climate change and the continuing threat of the attendant global warming [4]. A means to mitigate the climate change is by enhancement of soil carbonation for carbon capture and storage function [8].

The process of carbonation could be achieved by the reaction of alkaline earth oxides such as calcium oxide, or magnesium oxide with atmospheric $\mathrm{CO}_{2}$ to form carbonates of calcium or magnesium. The carbonation process is chemically represented by equations (1), (2) and (3).

$$
\begin{aligned}
& \mathrm{Ca}(\mathrm{OH})_{2}+\mathrm{CO}_{2} \rightarrow \mathrm{CaCO}_{3}+\mathrm{H}_{2} \mathrm{O} \\
& \mathrm{CaO}+\mathrm{CO}_{2} \rightarrow \mathrm{CaCO}_{3} \\
& \mathrm{MgO}+\mathrm{CO}_{2} \rightarrow \mathrm{MgCO}_{3}
\end{aligned}
$$

The carbonate (of calcium or magnesium) formed is usually classified as relatively weak cementing agent [10]. 


\section{AIM and OBJECTIVES of the STUDY}

The aim of this study was to determine whether combined carbon capture and strength improvement in lime treated soil could be achieved for application in capping layer of road pavement. The objectives were to determine the strength properties of carbonated compacted $\mathrm{Ca}(\mathrm{OH})_{2}$ treated kaolin and compare with those of non-carbonated treated kaolin. Compacted $\mathrm{Ca}(\mathrm{OH})_{2}$ treated kaolin is henceforth referred to as 'treated kaolin'. Other objectives were to determine calcium carbonate formation in carbonated treated kaolin for carbonation treatment. Furthermore, to determine if the strength improvement of carbonated treated kaolin are sufficient for application to capping layers in road pavement.

\section{MATERIALS and METHODS}

\section{III.A. Materials}

The soil used in this study was Imerys Polwhite Grade E kaolin clay. This is because its mineralogical simplicity avoids interference from effects associated with other clays within a natural soil that might be poorly characterised, and allows the work to be reproduced easily. This clay was supplied by IMERYS Minerals Ltd, UK. The mechanical and chemical composition of the clay is presented in Table 1 (details reported in [11]). The lime used was $\mathrm{Ca}(\mathrm{OH})_{2}$ supplied by Lafarge Tarmac Cement \& Lime, Buxton, UK. The chemical composition of the lime as provided by the manufacturer is also presented Table 1 . Sodium carbonate used in this study was supplied by VWR International, UK, its chemical composition again is shown in Table 1.

\section{III.B. Specimen Preparation}

To prepare treated kaolin specimens, lime content at $0 \%, 2 \%, 4 \%, 6 \%$ and $8 \% \mathrm{Ca}(\mathrm{OH})_{2}$ by weight each, kaolin clay and water were mechanically mixed, placed in airtight polythene bags and stored for 24 hours in a temperature controlled room $\left(20^{\circ} \mathrm{C}, 55 \%\right.$ relative humidity) in accordance with BS 1924, Part 2 [12]. By using $2.5 \mathrm{~kg}$ rammer (normal Proctor) compaction test, specimen of dimensions $38 \mathrm{~mm}$ diameter and $76 \mathrm{~mm}$ length were prepared based on the pre-calculated air voids content and densities in accordance with BS 1924, Part 2 [12]. The pre-calculated data is presented in Table 2 (details reported in [11]).

In order to simulate a critical moisture state for lime treated soil under reasonable pavement conditions, post 7 days cured specimens were soaked in water for 24 hours as required for low to moderate plasticity soils, according to the method by Little [13]. The soaking was carried out by allowing water to permeate through the specimen for 24 hours, using a triaxial cell set-up (shown in Fig. 1). Soaking of specimen using triaxial cell setup was selected in order to achieve similar soaking conditions in treated kaolin, which is further discussed in carbonation treatment section in this paper.

\section{III.C. Strength Testing}

To determine the strength of untreated kaolin, non-carbonated and carbonated treated kaolin specimens, unconfined compressive strength (UCS) testing was conducted using an INSTRON 5585H loading frame, at a strain rate of $1 \mathrm{~mm} / \mathrm{min}(1.3 \% / \mathrm{mm})$ in accordance with BS 1924-2 [12]. Three specimens were tested for each mix combination and the average value of the UCS was taken to represent the strength of the specimen. The strength tested specimens were retained for geochemical analysis.

\section{III.D. Modification and Carbonation Treatment}

A combination of modification and carbonation treatment were performed on treated kaolin to determine the resulting effect in terms of geochemical and strength improvement.

III.D.1) Modification Treatment: Modification treatment was conducted on treated kaolin clay to achieve short term reaction, which is typical within the early days of lime treated soil work. To provide for additional calcium ions that would be required by carbonation reaction, kaolin was treated with lime based on the result of the modified ICL test according to the definition presented by [2]. In the current study the ICL value was $4 \% \mathrm{Ca}(\mathrm{OH})_{2}$ by dry mass, which is equivalent of $3 \%$ calcium oxide $(\mathrm{CaO})$ content. Kaolin clay was mixed with $\mathrm{Ca}(\mathrm{OH})_{2}$ content equal to, and higher than ICL value. These were $4 \% \mathrm{Ca}(\mathrm{OH})_{2}$ (ICL value equivalent), $6 \% \mathrm{Ca}(\mathrm{OH})_{2}$ $(\mathrm{ICL}+1.5 \% \mathrm{CaO})$ and $8 \% \mathrm{Ca}(\mathrm{OH})_{2}(\mathrm{ICL}+3 \% \mathrm{CaO})$. Specimens of dimensions $38 \mathrm{~mm}$ diameter and $76 \mathrm{~mm}$ length were prepared and cured for 7 days in a temperature-controlled room $\left(20^{\circ} \mathrm{C}\right.$, and $55 \%$ relative humidity, as earlier described in Section IIIB). Short term curing of 7 days allows for short term reactions due to cation exchange, which is also referred to as soil modification [9]. These specimens were used for carbonation treatment. 
TABLE 1 Mechanical and Chemical Properties of Kaolin (Polwhite E), Lime and Sodium Carbonate as used in the Current Study

\begin{tabular}{|c|c|c|c|}
\hline Property & Kaolin & Lime & Sodium Carbonate \\
\hline \multicolumn{4}{|l|}{ Chemical composition ${ }^{\mathrm{a}}$} \\
\hline $\mathrm{SiO}_{2}(\operatorname{mass} \%)$ & 50 & 0.7 & 0.00005 \\
\hline $\mathrm{Al}_{2} \mathrm{O}_{3}$ (mass \%) & 35 & 0.1 & - \\
\hline $\mathrm{Fe}_{2} \mathrm{O}_{3}(\%)$ & - & 0.06 & - \\
\hline $\mathrm{Ca}(\mathrm{OH})_{2}(\%)$ & - & 96.9 & \\
\hline $\mathrm{Mg}(\mathrm{OH})_{2}(\%)$ & - & 0.5 & \\
\hline $\mathrm{CaSO}_{4}(\%)$ & - & 0.03 & \\
\hline $\operatorname{Mn}(\%)$ & - & $175 \mathrm{ppm}$ & \\
\hline$F(\%)$ & - & 65 ppm & \\
\hline $\mathrm{Pb}(\%)$ & - & $1.3 \mathrm{ppm}$ & \\
\hline As $(\%)$ & - & $0.3 \mathrm{ppm}$ & \\
\hline Phosphate $\left(\mathrm{PO}_{4}\right)$ & - & $0.001 \% \max$ & \\
\hline As $(\%)$ & - & $0.3 \mathrm{ppm}$ & \\
\hline Phosphate $\left(\mathrm{PO}_{4}\right)$ & - & $0.001 \% \max$ & \\
\hline Free moisture (\%) & - & 0.25 & \\
\hline Assay (dried basis) & - & - & $99.5 \% \mathrm{Na}_{2} \mathrm{CO}_{3} \min$ \\
\hline $\mathrm{SO}_{4}$ & - & - & $0.003 \% \max$ \\
\hline Chlorine $(\mathrm{Cl})$ & - & - & $0.0001 \% \max$ \\
\hline $\operatorname{Iron}(\mathrm{Fe})$ & - & - & 5 ppm max \\
\hline Calcium (Ca) & - & - & $0.03 \% \max$ \\
\hline Magnesium (Mg) & - & - & $0.005 \%$ \\
\hline Potassium (K) & - & - & $0.005(\%)$ \\
\hline Insoluble matter & & & $0.01 \% \max$ \\
\hline Loss on ignition (\%) & & & $1.0 \% \max$ \\
\hline \multicolumn{4}{|l|}{ Physical properties: } \\
\hline $0.06-0.002 \mathrm{~mm}(\%)$ & 65 & & \\
\hline Less than $0.002 \mathrm{~mm}(<2 \mu \mathrm{m})(\%)$ & 35 & & \\
\hline Surface area $\left(\mathrm{BET} ; \mathrm{m}^{2} / \mathrm{g}\right)$ & 8 & & \\
\hline $\mathrm{pH}$ & 5.5 & & \\
\hline Cation exchange capacity $(\mathrm{cmol} / \mathrm{kg})$ & 4.0 & & \\
\hline Specific gravity & 2.6 & & \\
\hline Liquid limit (\%) & 59 & & \\
\hline Plastic limit & 31 & & \\
\hline Plasticity index (\%) & 28 & & \\
\hline Optimum moisture content (\%) & 26.5 & & \\
\hline Maximum dry density $\left(\mathrm{Mg} / \mathrm{m}^{3}\right)$ & 1.44 & & \\
\hline Unconfined compressive strength $(\mathrm{kPa})^{\mathrm{b}}$ & 200 & & \\
\hline Initial consumption of lime (ICL) & $4 \% \mathrm{Ca}$ & & \\
\hline
\end{tabular}

${ }^{\mathrm{a}}$ Chemical analysis based on the supplier datasheet

${ }^{\mathrm{b}}$ At optimum moisture content 
TABLE 2 Compaction Target Specimen Data

\begin{tabular}{llllll}
\hline $\begin{array}{l}\text { Calcium } \\
\text { hydroxide content } \\
(\%)\end{array}$ & Air void (\%) & W (\%) & $\begin{array}{l}\text { Dry density } \\
\left(\mathrm{Mg} / \mathrm{m}^{3}\right)\end{array}$ & $\begin{array}{l}\text { Bulk density } \\
\left(\mathrm{Mg} / \mathrm{m}^{3}\right)\end{array}$ & Bulk mass (g) \\
\hline 4 & & $29^{\mathrm{b}}$ & 1.435 & 1.8512 & 160 \\
& $3^{\mathrm{a}}$ & 26 & 1.405 & 1.7703 & 152 \\
& 10 & 23 & 1.38 & 1.6974 & 147 \\
& 15 & 21 & 1.354 & 1.6383 & 141 \\
& 20 & 18 & 1.335 & 1.5753 & 136 \\
6 & 25 & $30^{\mathrm{b}}$ & 1.425 & 1.8525 & 159 \\
& $3^{\mathrm{a}}$ & 26 & 1.395 & 1.7577 & 152 \\
& 10 & 24 & 1.367 & 1.6951 & 146 \\
& 15 & 18 & 1.342 & 1.6238 & 140 \\
8 & 20 & $30^{\mathrm{b}}$ & 1.32 & 1.5616 & 135 \\
& 25 & 26 & 1.418 & 1.8434 & 159 \\
& $3^{\mathrm{a}}$ & 24 & 1.369 & 1.7501 & 151 \\
& 10 & 22 & 1.328 & 1.6864 & 145 \\
& 15 & 19 & 1.306 & 1.6202 & 139 \\
\hline
\end{tabular}

${ }^{\mathrm{a} A i r}$ void at maximum dry density (MDD), ${ }^{b}$ Moisture content at optimum moisture content (OMC).

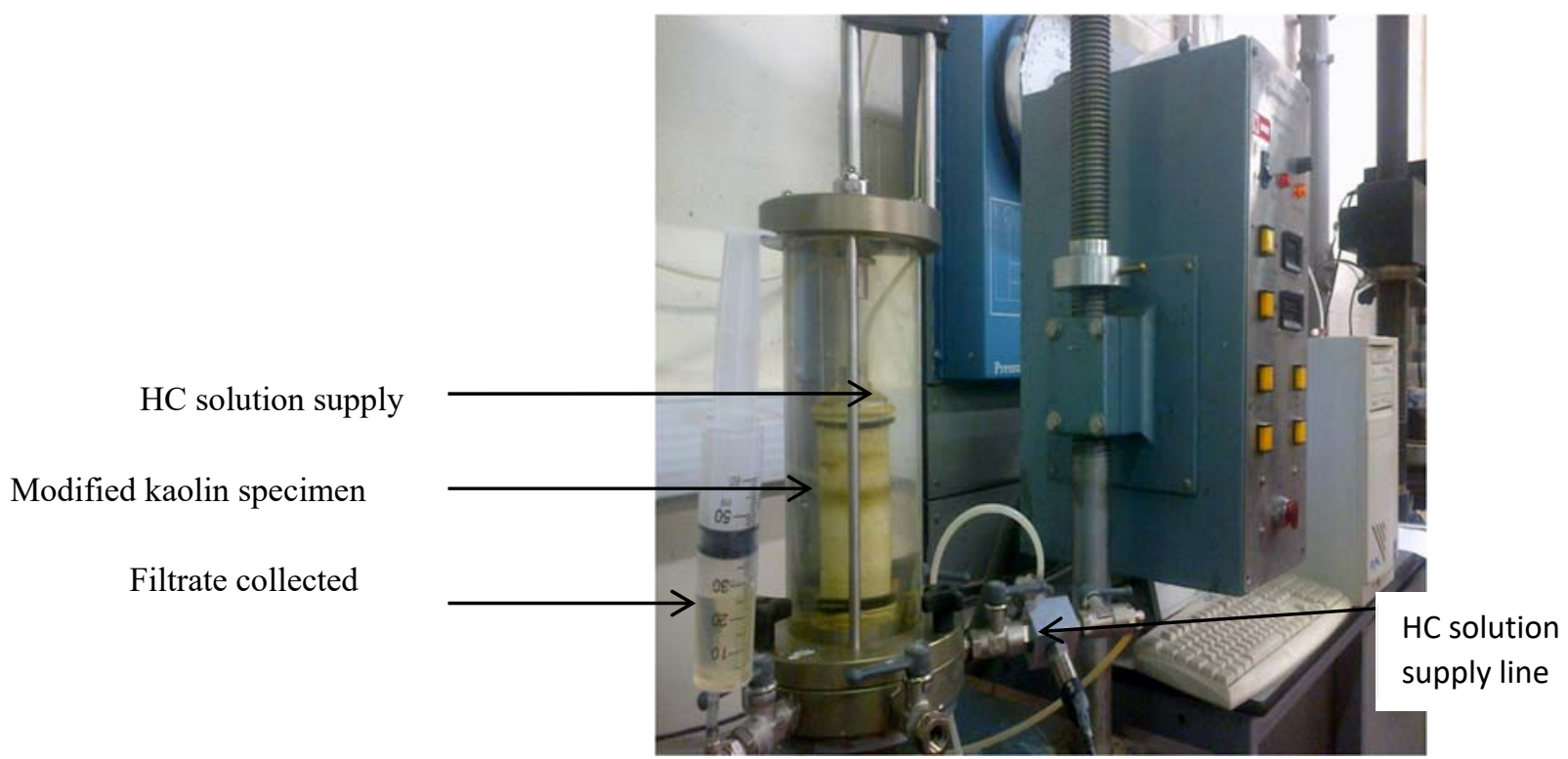

Fig. 1. Carbonation treatment of calcium hydroxide treated kaolin clay using triaxial cell set-up (modified from BS 1377-6: [14]). HC represents high carbon.

III.D.2) Carbonation Treatment: To achieve carbonated lime treated specimens, carbonation treatment experiment was conducted on post modified treated kaolin specimens based on the permeability in a triaxial cell test in accordance with BS 1377-6 [14]. The triaxial cell used in this study was fitted with a measurement and control system (Geotechnical Digital Systems: GDS) having automatic pressure and volume control units (Fig.1).

In order to perform the carbonation treatment, high carbon (HC) solution (made up of 1 molar sodium carbonate $\left(\mathrm{Na}_{2} \mathrm{CO}_{3(\mathrm{aq})}\right)$ ) was permeated downward through the treated kaolin specimen at gauge pressure of 100 $\mathrm{kPa}$, and cell confining pressure of $150 \mathrm{kPa}$. The filtrate was collected through the syringe at intervals of 1 hour until the carbonation treatment was completed. The carbonation treatment was considered completed when the electrical conductivity (EC) of the filtrate was the same as the EC of the supplied HC solution. The EC of the filtrate was determined using a microprocessor controlled electrical conductivity/TDS meter (HANNA HI 9835 model) in accordance with BS 7755-3.4 [15].

\section{III.E. Geochemical Testing}

Geochemical testing was carried out using a calcimeter and thermogravimetric analysis (TGA). Calcimeter analysis was performed on 15 samples of carbonated treated kaolin to confirm the presence and 
quantify $\mathrm{CaCO}_{3}$ content in adherence with BS EN ISO 10693 [16]. The technique determines carbonates in a sample based on a volumetric approach. Thermogravimetry - differential scanning calorimetry coupled with quadrupole mass spectrometry (TG-DSC-QMS) was performed on carbonated treated kaolin to confirm the presence and quantify precisely the amount of $\mathrm{CaCO}_{3}$ content. Due to the cost and time involved in each test, TGA was performed on 3 samples with remarkable strength corresponding to carbonated treated kaolin at $10 \%$ air voids value with $4 \%, 6 \%$ and $8 \% \mathrm{Ca}(\mathrm{OH})_{2}$ contents respectively. This analysis was performed using Netzsch STA449C Jupiter TG-DSC system at Newcastle University, UK (details reported in [11]). TGA measures the mass loss as a function of temperature, and allows for a discrete quantification of $\mathrm{CaCO}_{3}$ and other heat-sensitive soil component.

\section{III.F. Scanning Electron Microscopy}

Scanning Electron Microscopy (SEM) analysis was performed on non-carbonated and carbonated treated kaolin samples to confirm the presence of $\mathrm{CaCO}_{3}$. In this study, an FEI XL30 environmental scanning electron microscope (XL30 ESEM) at Newcastle University, UK was used. It is fitted with a field emission gun, and a Centaurus backscattered electron detector to collect the images reproduced. A point elemental analysis was performed on the crystal grains within the sample to determine mineral elements using a Rontec Quantax Energy Dispersion X-ray analyser (EDX) attached to the environmental scanning electron microscope (ESEM). Due to cost and time involved two samples (broken sections) were analysed. The samples were selected to represent the non-carbonated and carbonated lime treated kaolin at highest lime content $\left(8 \% \mathrm{Ca}(\mathrm{OH})_{2}\right)$ which was expected to undergo highest mineral changes due to carbonation.

\section{RESULTS}

\section{IV.A. Strength Improvement of Non-carbonated Lime Treated Kaolin}

The experimental results investigating the strength of 7 days cured water saturated treated kaolin are shown in Fig.2. The treated kaolin was compacted to maximum dry density (3\% air voids) prior to soaking in water for 24 hours (as described in Section III.B). The results show that a peak 7 days cured UCS of $200 \mathrm{kPa}$ was achieved at $4 \% \mathrm{Ca}(\mathrm{OH})_{2}$ addition.

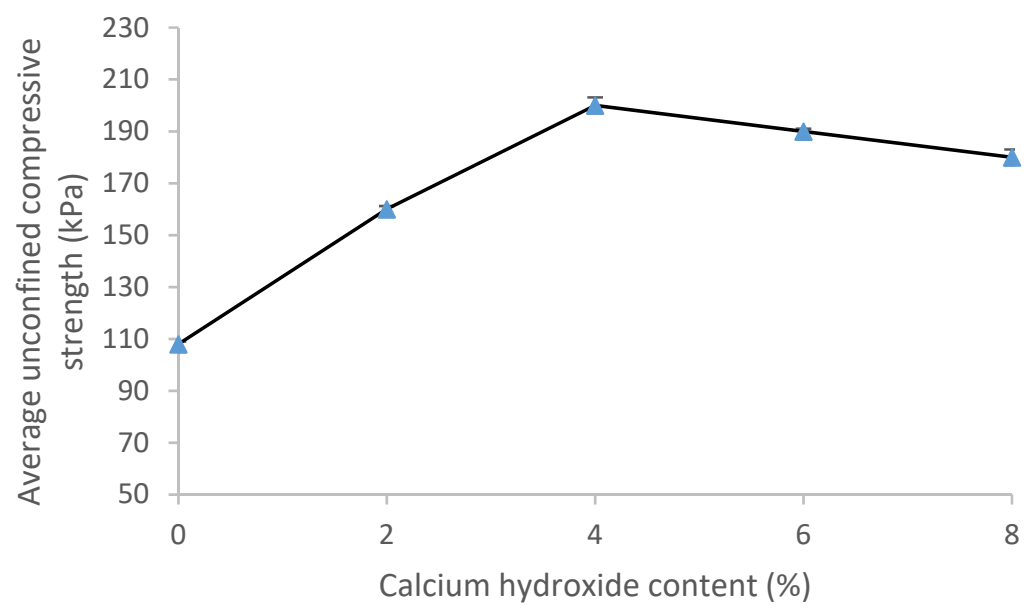

Fig. 2. Variation of unconfined compressive strength (UCS) of water saturated calcium hydroxide treated kaolin compacted to $3 \%$ air voids (average of 3 samples per point, cured for 7 days). Analytical error bars represent 1 standard deviations.

\section{IV.B. Effect of Calcium Hydroxide Addition on Calcium Carbonate Formation}

The experimental results showing the effect of increasing $\mathrm{Ca}(\mathrm{OH})_{2}$ additions on $\mathrm{CaCO}_{3}$ formation are shown in Figs.3a, and 3b. The results derived from Eijkelkamp calcimeter analysis are shown in Fig. 3a, whilst results obtained from TGA analysis for samples at $10 \%$ air voids is shown in Fig. 3b. Overall, the amount of $\mathrm{CaCO}_{3}$ increased proportionally with $\mathrm{Ca}(\mathrm{OH})_{2}$ content in the treated kaolin (Fig. 3a). It may be seen that doubling the $\mathrm{Ca}(\mathrm{OH})_{2}$ additions doubles the $\mathrm{CaCO}_{3}$ formed and may be predicted from equation 1, where $\mathrm{Ca}(\mathrm{OH})_{2}$ addition is proportional to the resulting $\mathrm{CaCO}_{3}$. Analysing carbonate content in Fig. 3b, the peak characteristic between 660 and $740^{\circ} \mathrm{C}$ shows mass loss from decarbonation reactions $\left(\mathrm{CO}_{2}\right.$ derived from calcite, $\left.\mathrm{CaCO}_{3}\right)$, and the results are presented in Table 3.

There is excellent agreement between the two techniques for determining $\mathrm{CaCO}_{3}$ content. The results of T-test conducted on $\mathrm{CaCO}_{3}$ in Table 3 indicates that, there was no significant difference between the results from TGA and calcimeter at $p=0.10$. This is due to the consideration that if the $p$-value is greater than 0.05 , then the results are similar (in this case results from the techniques), else they are not. Additionally, the results of 
$\mathrm{CaCO}_{3}$ content derived from the two methods were in reasonable agreement with the theoretical $\mathrm{CaCO}_{3}$ content (Table 3).

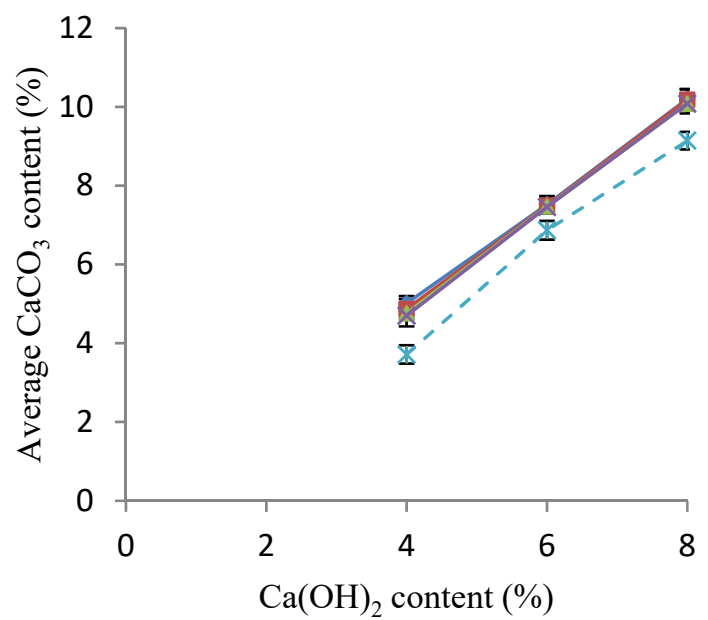

(a)

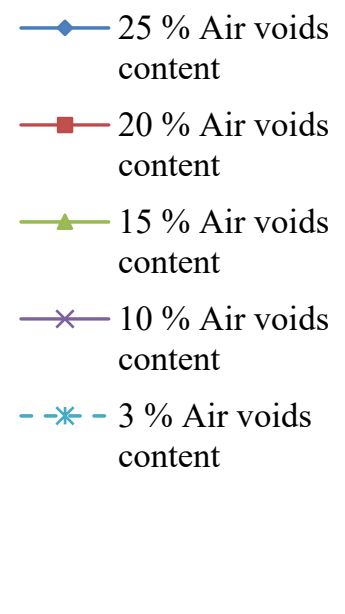




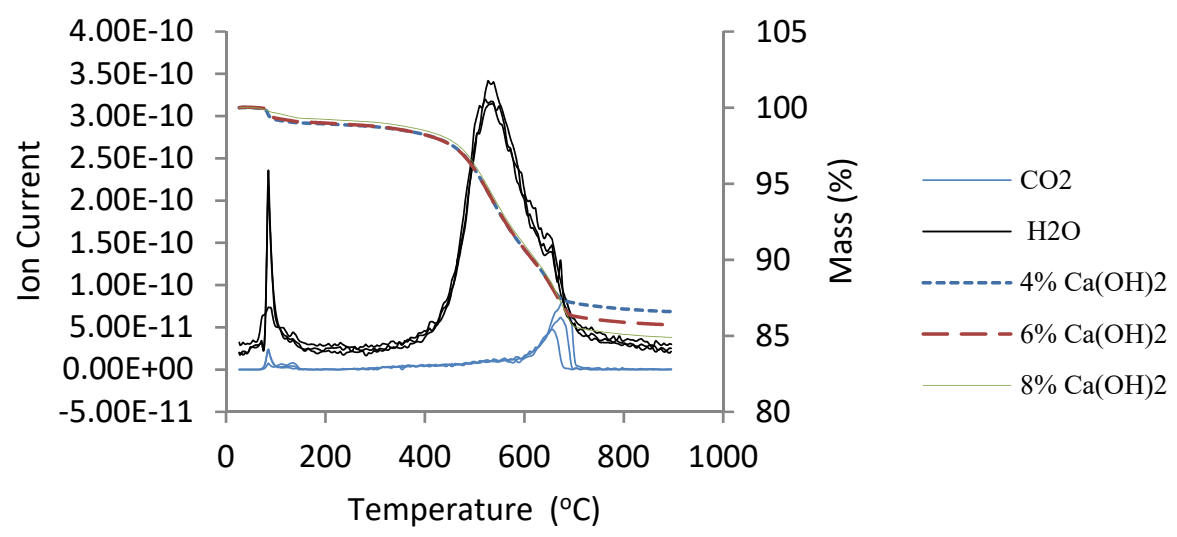

Fig. 3a. Calcium carbonate content in kaoli (b) arying calcium hydroxide $\left(\mathrm{Ca}(\mathrm{OH})_{2}\right)$ additions obtained from calcimeter analysis (average of 3 samples per point). Analytical error bars represent 1 standard deviation (b) Combine thermogravimetric curve and QMS trace, evolved gas $\left(\mathrm{H}_{2} \mathrm{O}\right.$ and $\left.\mathrm{CO}_{2}\right)$ for samples at $10 \%$ air void (average of 3 samples per combination).

TABLE 3 Calcium Carbonate Content from Thermogravimetric Analysis (TGA) and Calcimeter Analysis for Sample at 10\% Air Voids Content.

\begin{tabular}{lllll}
\hline $\begin{array}{l}\mathbf{C a}(\mathbf{O H})_{2} \\
\text { content } \\
(\%)\end{array}$ & $\begin{array}{l}\mathrm{Theoretical}^{\mathrm{T}} \mathbf{C a C O}_{3}(\%) \\
{ }^{\mathrm{a}} \mathbf{C a C O}_{3} \\
\text { content from } \\
\text { TGA }(\%)\end{array}$ & $\begin{array}{l}{ }^{\mathrm{b}} \mathbf{C a C O}_{3} \text { content } \\
\text { from calcimeter } \\
(\%)\end{array}$ & $\begin{array}{l}\text { Comparison of } \mathbf{C a C O}_{3} \\
\text { results in TGA versus } \\
\text { Calcimeter }\end{array}$ \\
\hline 4 & 5.40 & $4.54 \pm 0.21$ & $4.70 \pm 0.24$ & - \\
6 & 8.11 & $6.97 \pm 0.13$ & $7.46 \pm 0.16$ & - \\
8 & 10.81 & $9.40 \pm 0.23$ & $10.08 \pm 0.15$ & - \\
P-value & & & & 0.10 \\
\hline
\end{tabular}

${ }^{\mathrm{a}}$ Analytical error from TGA based on 1 standard deviation ranged from \pm 0.13 to $\pm 0.23 \% \mathrm{wt} \mathrm{CaCO}_{3} .{ }^{\mathrm{b}}$ Analytical error from calcimeter based on 1 standard deviation (average of 3 samples per combination) ranged from \pm 0.15 to $\pm 0.24 \%$ wt $\mathrm{CaCO}_{3}$.

Note: TGA represents thermogravimetric analysis, $\mathrm{Ca}(\mathrm{OH})_{2}$ represents calcium hydroxide, and $\mathrm{CaCO}_{3}$ represents calcium carbonate.

- Represents not applicable.

\section{IV.C. Scanning Electron Microscopy Analysis}

Broken section of non-carbonated and carbonated treated kaolin samples were analysed using an XL30 ESEM. Due to the cost and time involved only two samples (both of 8L10AV treated) were analysed. 8L10AV treated sample was selected because of its highest $\mathrm{CaCO}_{3}$ content based on TGA analysis (previously presented in Fig. 3b). The SEM images of non-carbonated and carbonated treated kaolin samples are presented in Figs. 4(a)-4(b). Point elemental analysis performed on the red spots (Points 1 and 2) is presented in Fig. 5. It is known that the use of SEM secondary electron images (SEI) combined with energy dispersion analysis (EDA) is primarily an imaging method and not a fully quantitative approach [17]. It is difficult to identify $\mathrm{CaCO}_{3}$ unambiguously using this approach. As reported in Section IV.B, thermal analysis unambiguously demonstrated the presence of $\mathrm{CaCO}_{3}$ in the sample, which were used for SEM.

Figs. 4(a) and 4(b) show the texture before and after carbonation treatment. The images show many amorphous white patches and white flaky crystals. On the basis of their morphology, it is suggested that the flaky grains are kaolinite particles. Grains with a less clear morphology could be $\mathrm{CaCO}_{3}$. These grains were about 2-3 $\mu \mathrm{m}$ in size. Point elemental analysis performed on areas of the sample indicated the presence of a range of elements including calcium (Fig. 5) suggesting $\mathrm{CaCO}_{3}$. Other elements such as $\mathrm{Si}$ and $\mathrm{Al}$ were seen, suggesting kaolinite. The SEM-EDA system cannot resolve grains as small as 2-3 $\mu \mathrm{m}$, and so the spectra represent an analysis of a composite mixture of kaolin and calcite. 


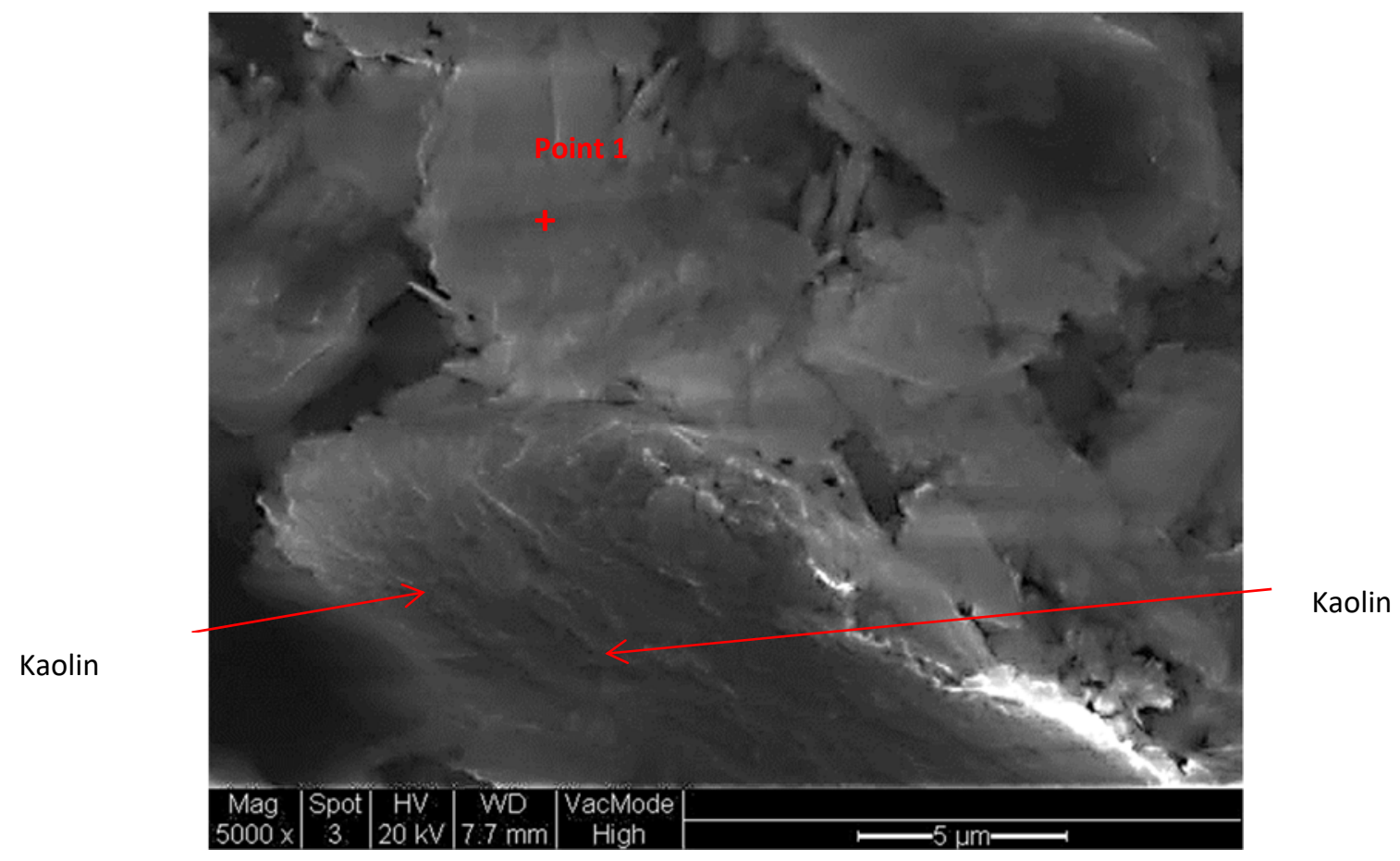

Fig. 4 (a): Broken section of 8L10AV non-carbonated treated kaolin, spots: $\mathrm{L}=$ Percentage $\mathrm{Ca}(\mathrm{OH})_{2}$ Content, $\mathrm{AV}=$ Air Voids Content

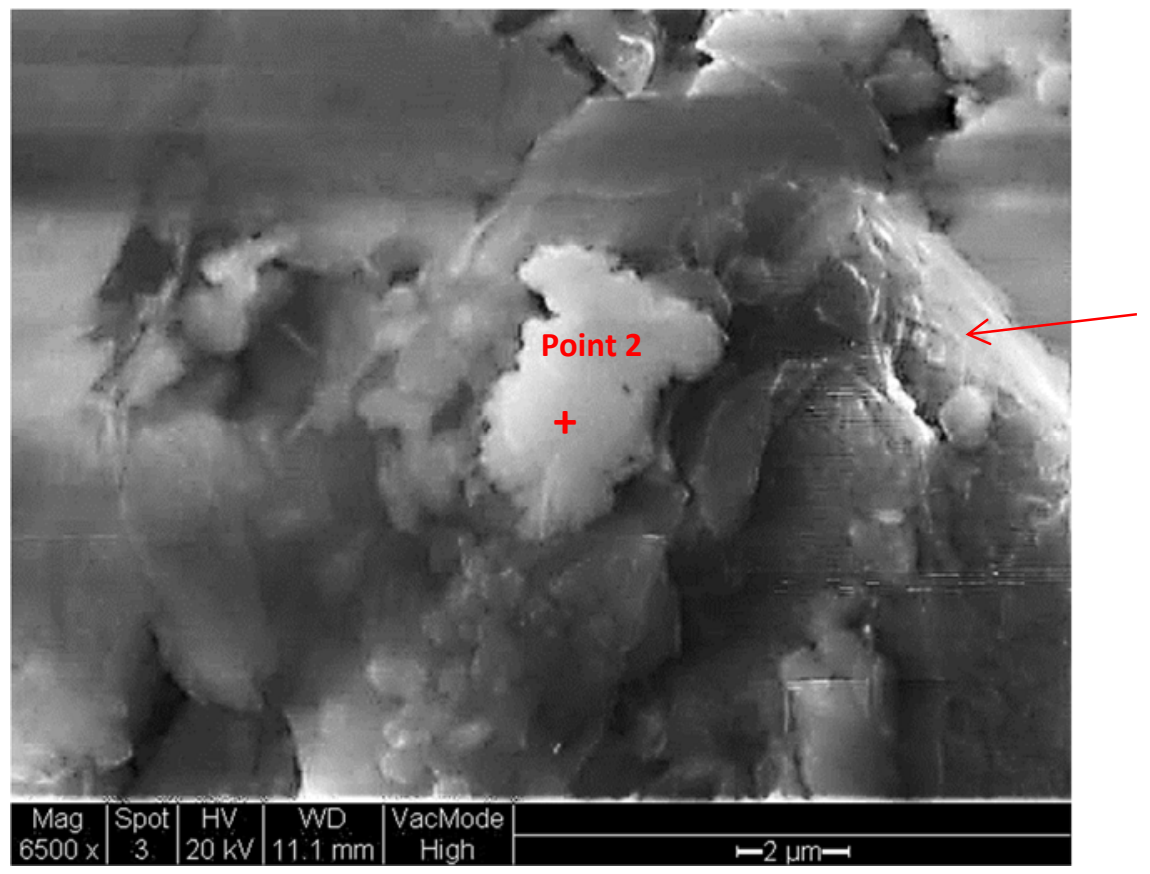

Fig. 4(b): Polished Section of $8 \mathrm{~L} 10 \mathrm{AV}$ Carbonated treated kaolin, Spot Point $2=\mathrm{CaCO}_{3}, \mathrm{~L}=$ Percentage $\mathrm{Ca}(\mathrm{OH})_{2}$ Content, $\mathrm{AV}=\mathrm{Air}$ Voids Content 


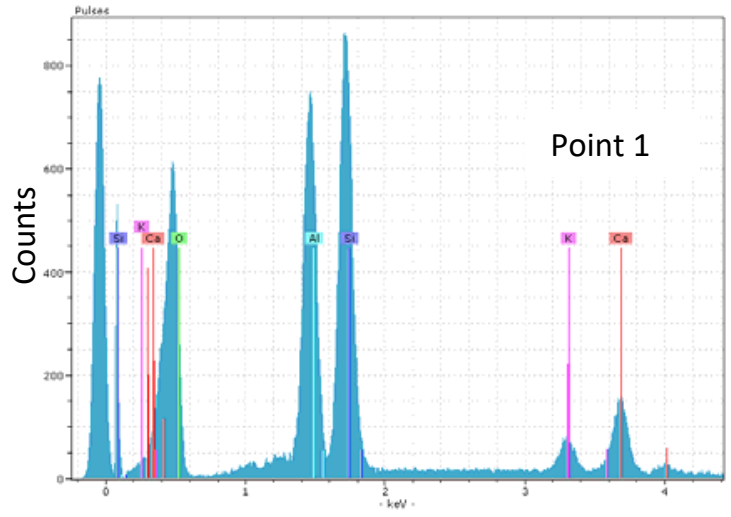

(a)

Energy (keV)

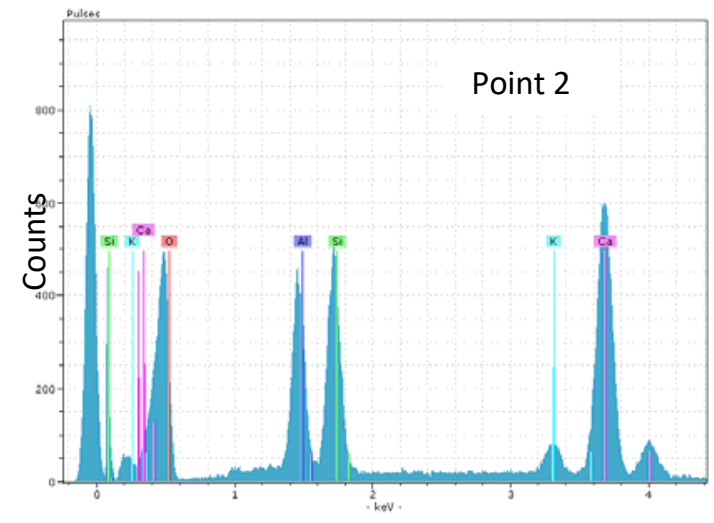

(b)

Energy (keV)

Fig. 5: Elemental Analysis Points 1-2 from Figs. 4a-4b.

\section{IV.D. Effect of Calcium Hydroxide Additions on the Strength of Carbonated Treated Kaolin}

The experimental results investigating the effect of increasing $\mathrm{Ca}(\mathrm{OH})_{2}$ additions on the strength of carbonated treated kaolin are shown in Fig. 6. The results show that the peak UCS was achieved in specimens with $6 \% \mathrm{Ca}(\mathrm{OH})_{2}$ content (for all air voids contents). Generally, the lime content in treated soil at which peak strength is achieved is referred to as optimum lime content [18]. In the current study, $6 \% \mathrm{Ca}(\mathrm{OH})_{2}$ shows to be the optimum lime content in the carbonated treated kaolin.

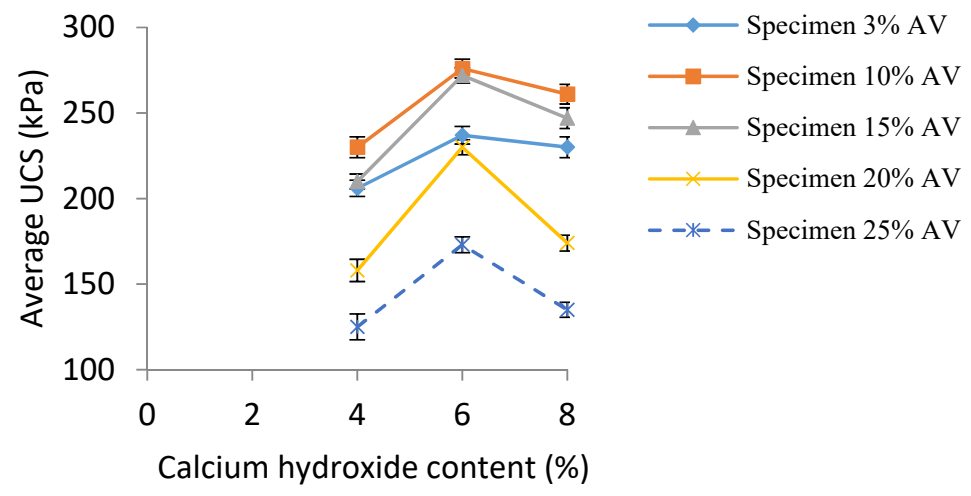

Fig. 6. Effect of calcium hydroxide additions on unconfined compressive strength (UCS) of carbonated treated kaolin (average of 3 samples per point). Analytical error bars represent 1 standard deviation. AV represents air voids content

Usually non-carbonated treated soil would have less strength compared with carbonated treated soil [19]. As noted by Bell [1], peak strength for lime treated soils is obtained when optimum lime content is attained. Considering Fig. 6 for sample compacted to air voids of $3 \%$, an optimum lime content of $6 \% \mathrm{Ca}(\mathrm{OH})_{2}$ achieves peak strength of $240 \mathrm{kPa}$ for carbonated treated kaolin. Comparing this optimum lime content of carbonated treated kaolin with water saturated non-carbonated treated kaolin at $6 \% \mathrm{Ca}(\mathrm{OH})_{2}$ (Fig. 2), it is observed that the carbonated treated kaolin has higher strength of $240 \mathrm{kPa}$ as compared to a strength of $190 \mathrm{kPa}$ for the water saturated non-carbonated treated kaolin.

\section{IV.E. Variation of Strength with Air Voids Content}

The experimental results investigating the variation of strength with the set air voids of carbonated treated kaolin are shown in Fig. 7. The UCS of the carbonated specimens increased with increasing air voids up to $10 \%$, and then decreased with further increases in air voids above $10 \%$. The specimens at $10 \%$ air voids content showed the highest strength. It is observed that the specimen at $10 \%$ air voids content also exhibited significant $\mathrm{CaCO}_{3}$ content as presented in Section IV.B. 


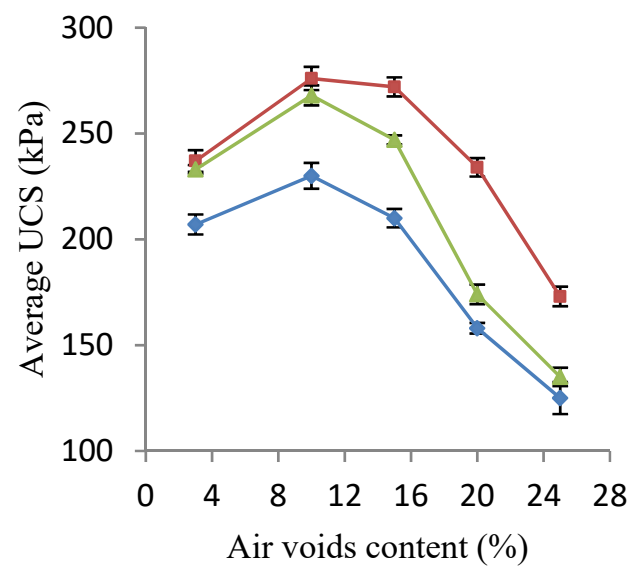

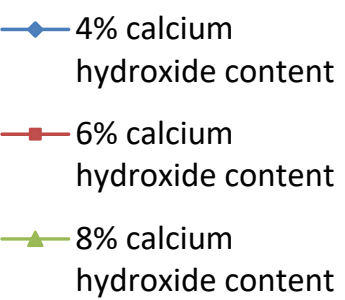

hydroxide content

Fig. 7 Unconfined compressive strength variation with air voids content of carbonated treated kaolin (average of 3 samples per point). Analytical error bars represent 1 standard deviation

\section{IV.F. Unconfined Compressive Strength Variation with Calcium Carbonate Content}

Fig. 8 shows the UCS variations with $\mathrm{CaCO}_{3}$ content in carbonated treated kaolin. The results shows that the highest strength for all calcium carbonate contents was achieved at $10 \%$ air voids. This data supports the findings that air voids content of $10 \%$ resulted in notable $\mathrm{CaCO}_{3}$ content and peak strength in carbonated treated kaolin.

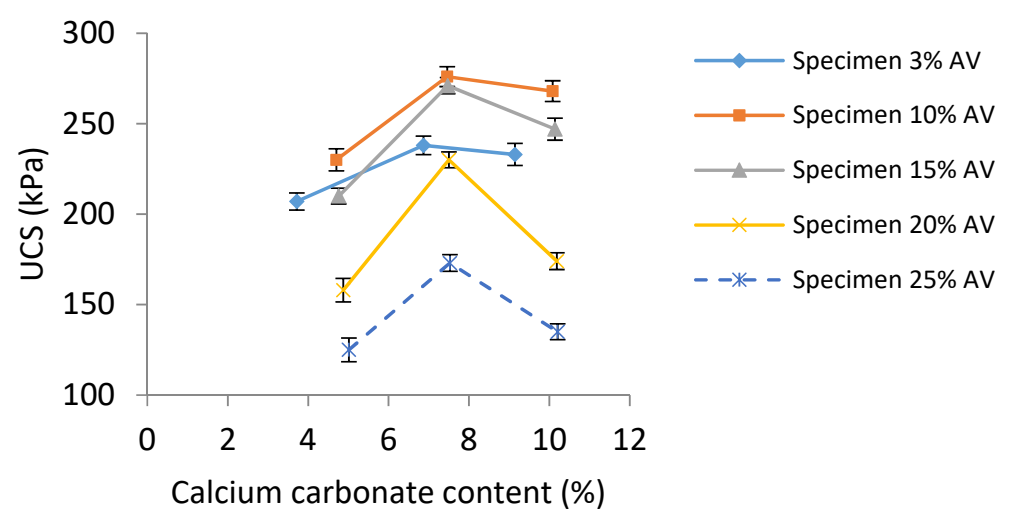

Fig. 8. Variation of unconfined compressive strength (UCS) with calcium carbonate content in carbonated treated kaolin (average of 3 specimens per point). Error bars represent 1 standard deviation.

\section{DISCUSSION}

The data presented in this paper show that carbonation reaction in treated kaolin could result in combined calcium carbonate formation, and strength improvement. This could be influenced by the air voids contents under which they are compacted. It is shown that a control of air voids content of treated kaolin produces a desired effect of carbonation reaction for a combined carbon capture and strength improvement. These improvements are important for mitigation of climate change, alongside ground stability. There is a practical application of this study for climate change mitigation, as this approach could significantly offset $\mathrm{CO}_{2}$ released from lime production.

\section{V.A. Degree of Carbonation and Lime Additions}

The results showing the degree of carbonation (DOC) as a function of $\mathrm{Ca}(\mathrm{OH})_{2}$ additions in treated kaolin using calcimeter data are presented in Fig. 9. The DOC is a common means to assess the extent of carbonation. This allows for quantification of the experimentally determined carbonates of cation-rich material relative to the amount of carbonates that would be formed if a complete carbonation of available cations was achieved [20]. DOC has been determined as:

$$
\mathrm{DOC}=\frac{\mathrm{MCO}_{2(\mathrm{~d})}}{\mathrm{MCO}_{2}(\mathrm{th})}
$$

where $\mathrm{MCO}_{2}$ (d) is the amount of experimentally determined carbonate, and $\mathrm{MCO}_{2}$ (th) is the amount of theoretically determined carbonate based on stoichiometry.

The amount of theoretical carbonation for pure oxides of lime $\left(\mathrm{CaO}\right.$ or $\left.\mathrm{Ca}(\mathrm{OH})_{2}\right)$ is chemically derived by 
equations (1) and (2)

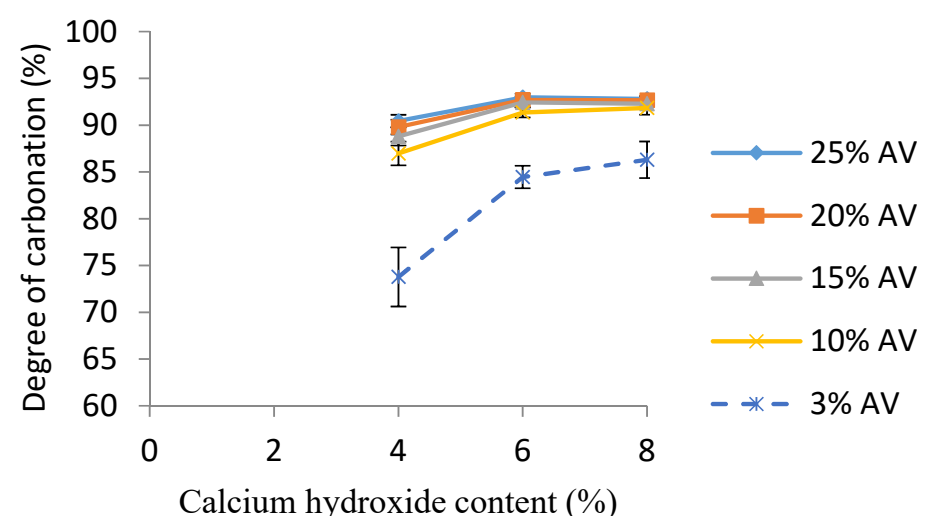

Fig. 9. Variation in degree of carbonation with calcium hydroxide content in treated kaolin (error bars are based on one standard deviation). AV represents air voids content

In all the cases based on the DOC, the combination of $6 \% \mathrm{Ca}(\mathrm{OH})_{2}$ content and $20 \%$ air voids content $(6 \mathrm{~L} 20 \mathrm{AV})$ was found as the minimum mixture that produced the highest $\mathrm{CaCO}_{3}$ in the treated kaolin. The maximum DOC derived from the Eijkelkamp calcimeter analysis in the current study was $93 \% .100 \%$ DOC was not attained; this could be due to incomplete dissolution of calcium hydroxide into pore solution where carbonation occurs. The combination of $6 \% \mathrm{Ca}(\mathrm{OH})_{2}$ content and $20 \%$ air voids content in kaolin gives the maximum $\mathrm{CO}_{2}$ removed.

\section{V.B. Degree of Carbonation and Air Voids Content}

The effect of increasing air voids contents on carbonation in treated kaolin is presented in Fig. 10. Equivalent $\mathrm{CaO}$ was determined from the $\mathrm{Ca}(\mathrm{OH})_{2}$ used in the current study for comparison with magnesia $(\mathrm{MgO})$ used by [19], [21]. $\mathrm{CaO}$ and $\mathrm{MgO}$ are both stabilizers used for soil improvement, and have similar mechanisms of carbonation reaction for strength improvement of soil.

There is however a shortcoming in this comparator because different researchers used different clays. The current study used pure kaolin clay for $\mathrm{CaO}$ treatment, whilst [19] used clayey silty sand for $\mathrm{MgO}$ treatment, and [21] used lean clay soil for $\mathrm{MgO}$ treatment.

To plot Fig. 10, moisture content and density data from [19], [21] were used to calculate the equivalent air voids content, and DOC data were taken directly from their report. For clarity the results in the current study have been separated into two distinct stages and plotted in Fig. 11.

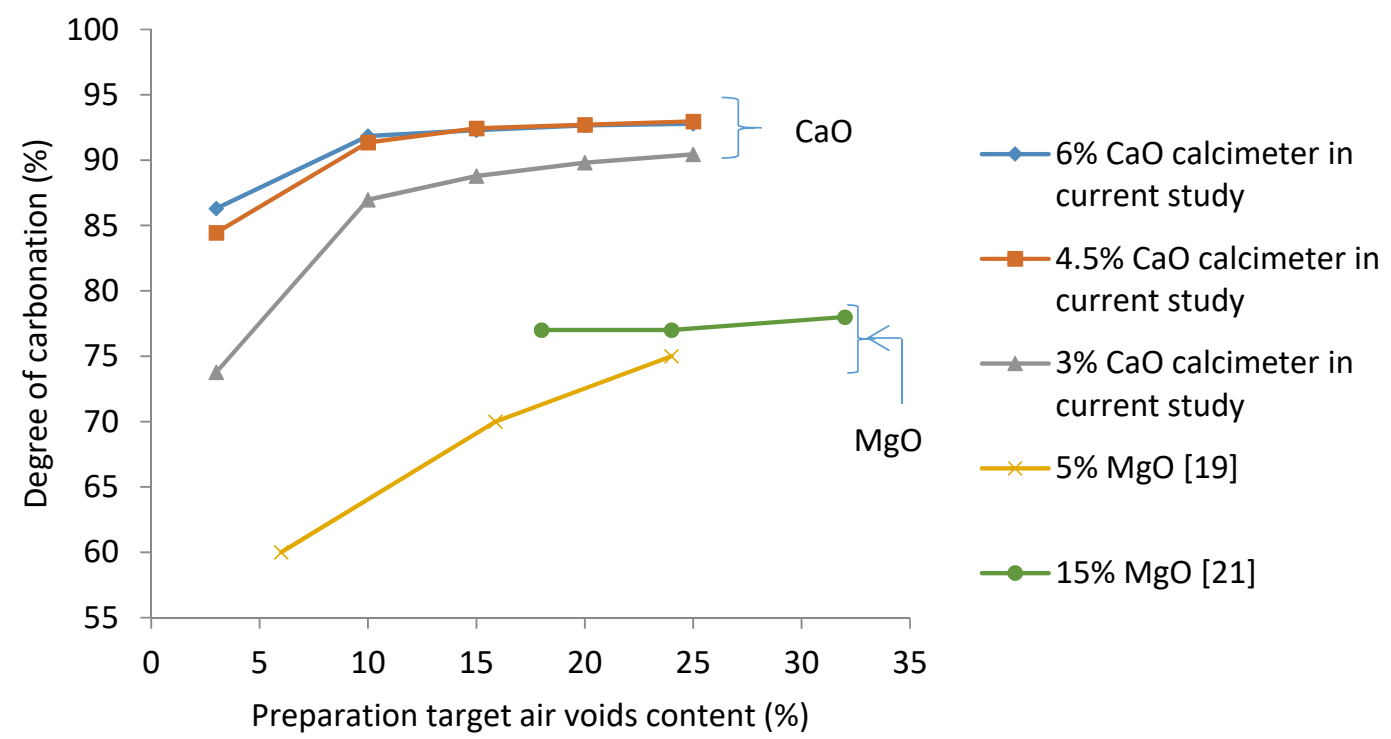

Fig. 10. Degree of carbonation (DOC) development as a function of air voids in calcium oxide (CaO) treatment in the current study and magnesium oxide (MgO) treatment after [19], [21] 


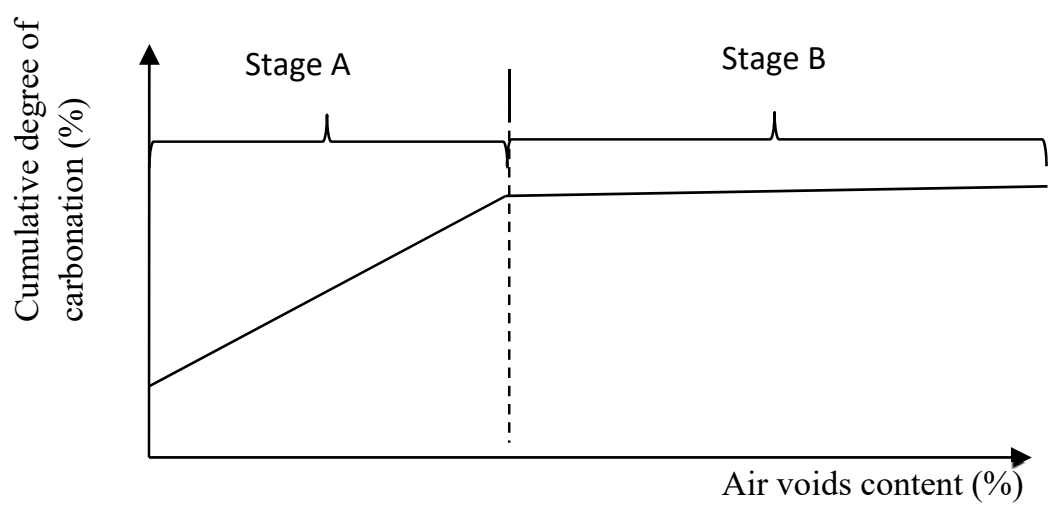

Fig. 11. Two Stages of the degree of carbonation (DOC) with air voids at constant calcium oxide content

In the first stage (A), the cumulative $\mathrm{DOC}$ of $\mathrm{CaO}$ has a linear relationship with the air voids content. The relationship remained until the air voids value reached a limit ( $10 \%$ in the current study). Above the limiting air voids value only marginal increases in DOC were observed. Throughout stage A, the air voids value of the soil increased and resulted in increased DOC. During the second stage (B) negligible further carbonation occurs on further increase in air voids content, because the lime has been consumed.

The linear relationship of cumulative DOC with air voids content in the current study (first stage (A) Fig. 11) is similar to that produced by [19] for carbonated $\mathrm{MgO}$ treated clayey silty sand (Fig. 10). The similar pattern observed for both studies suggests that there is an air voids content in $\mathrm{CaO}$ treated kaolin for achieving desirable carbonation (as the asymptote of carbonation curve is approached), in the current study $10 \%$ air voids. It is noted that the $10 \%$ air voids value corresponds to the peak strength (particularly UCS), and this is further discussed in Section V.D. It is observed that the limiting air voids for remarkable $\mathrm{DOC}$ is more distinct in $\mathrm{CaO}$ treatment than that in $\mathrm{MgO}$ : this could be because more of the $\mathrm{CaO}$ has been dissolved and so reacted, and that $\mathrm{MgO}$ does not dissolve as easily.

The carbonation reaction in treated kaolin is influenced by the air voids contents under which they are compacted. The current study has found that a control of air voids content of treated kaolin produces a desired effect of carbonation reaction for a combined carbonation and strength improvement. In practical application air voids would be controlled in treated kaolin by compaction at the dry side of optimum moisture content (OMC), because it produces high air voids [22].

A field trial would be required to determine the most efficient type of compaction plant for method 7 of Specification for Highway Works [23], and the number of passes suitable for achieving the desired air voids contents. Method 7 is required for the compaction of stabilized material (7E) for capping layer of class (9E) (Table 6/4, Specification for Highway Works [23]. This would require addition of the pre-determined water content to the soil, in situ lime treatment, running the compaction plant over the material, and measuring the dry density of the material at given number of passes. This would be used to determine the most economical plant that achieves the desired air voids content.

\section{V.C. Carbonation and Strength Improvement}

Carbonation of lime treated kaolin in the current study resulted in strength improvement (previously presented in Section IV.D). One of the objectives of this study was to determine whether carbonated treated kaolin could achieve acceptable strength increase sufficient for application to capping layer in road pavement. The strength improvement of saturated carbonated treated kaolin compared with that of equivalent saturated noncarbonated treated kaolin based on 7 days curing is presented in Table 4 . The strength improvement is expressed as strength improvement factor (SIF). The SIF of carbonation is derived as the multiplier of the strength of carbonated treated specimen compared with the strength of the corresponding non-carbonated specimen, as also determined by [24]. The SIF of carbonated treated kaolin shows slight increases of up to 1.6 (Table 4).

Based on 7 days curing, the highest compressive strength of saturated carbonated treated kaolin of up to $280 \mathrm{kPa}$ was achieved with $6 \mathrm{~L} 10 \mathrm{AV}$ specimen in the current study. This strength is higher than the undrained shear strength of treated kaolin which is approximately $80 \mathrm{kPa}$ in [25]. The reason for this could be that different researchers used different lime content. The current study used minimum of $3 \% \mathrm{CaO}$ equivalent content, whilst [25] used maximum of $2.5 \% \mathrm{CaO}$ content.

Similar results of increase in SIF in carbonated magnesia treated soil is presented by [21], who reported a SIF of approximately 14 for a specimen with $15 \% \mathrm{MgO}$ at $24 \%$ air voids content combination (Table 4 ). The 
SIF of carbonated lime treated kaolin is approximately 9 times lower than that produced by magnesia treated lean clay. Magnesia treatment produced higher strength than that produced with lime treatment, because different researchers used different soils. The current study used pure kaolin, whilst [21] used a lean clay soil. The pure kaolin in the current study composed of $35 \%$ clay (grain size $<0.002 \mathrm{~mm}$ ) and $65 \%$ silt (grain size $0.002 \mathrm{~mm}-0.075$ $\mathrm{mm}$ ), whilst the lean clay soil in [21] composed of $6.4 \%$ clay (grain size $<0.002 \mathrm{~mm}$ ), $75.7 \%$ silt (grain size $0.002 \mathrm{~mm}-0.075 \mathrm{~mm}$ ), and $17.9 \%$ sand (grain size $0.075 \mathrm{~mm}-2 \mathrm{~mm}$ ). The strength improvement in [21] may reflect carbonate cement formation that binds sand grains together. So the results reflect the strength of quartz, which is the mineral likely to be in the silt and sand fractions. Although the strength improvement results are not directly comparable due to very different clay used in each study, the observed improvement in strength indicates the improvement produced due to carbonation. Whereas, $\mathrm{CaO}$ seems to produce far lower strengths than $\mathrm{MgO}$, the potential DOC is greater in $\mathrm{CaO}$ carbonation (Section V.B).

The peak UCS $(280 \mathrm{kPa})$ in carbonated treated kaolin in the current study was achieved at $6 \% \mathrm{Ca}(\mathrm{OH})_{2}$ ( $4.5 \% \mathrm{CaO}$ equivalent), and $10 \%$ air void combination. For comparison purpose, the peak UCS was expressed in terms of California bearing ratio (CBR) as represented in Equation (5) [26].

$$
\mathrm{CBR}=0.56 S u^{1.07}
$$

where $S u$ is the UCS (in pound-force per square inch, psi). The UCS of $280 \mathrm{kPa}$ was converted to psi unit using $1 \mathrm{kPa}=0.145 \mathrm{psi}$ (that is $280 \mathrm{kPa}=40.60 \mathrm{psi}$ )

Therefore the $\mathrm{CBR}=0.56 *(40.60)^{1.07}=29 \%$

Considering that the carbonated treated kaolin in the current study has an equivalent CBR of $29 \%$, it is observed to be greater than the CBR value of $15 \%$ which is the minimum CBR value required for stabilized capping layer [27]. Based on strength requirements, the carbonated treated kaolin is suitable for use as a stabilized capping layer.

TABLE 4 Compressive Strength Improvement of Carbonated Treated Soil Specimen Relatively to Non-carbonated Treated Soil Specimen

\begin{tabular}{|c|c|c|c|c|c|c|c|c|c|}
\hline Author & $\begin{array}{l}\text { Soil } \\
\text { description }\end{array}$ & $\begin{array}{l}\mathrm{CaO} \\
\text { content } \\
(\%)\end{array}$ & $\begin{array}{l}\mathrm{MgO} \\
\text { content } \\
(\%)\end{array}$ & $\begin{array}{l}\text { Sample } \\
\text { Description }\end{array}$ & $\begin{array}{l}\text { UCS of } \\
\text { water } \\
\text { saturated } \\
\text { non- } \\
\text { carbonate } \\
\text { treated } \\
\text { kaolin } \\
\text { specimen } \\
(\mathrm{kPa})\end{array}$ & $\begin{array}{l}\text { UCS of } \\
\text { non- } \\
\text { carbonate } \\
\mathrm{MgO} \\
\text { treated } \\
\text { lean clay } \\
\text { soil } \\
\text { specimen } \\
(\mathrm{kPa})\end{array}$ & $\begin{array}{l}\text { UCS of } \\
\text { carbonated } \\
\text { treated soil } \\
\text { specimen } \\
(\mathrm{kPa})\end{array}$ & $\begin{array}{l}{ }^{\mathrm{d}} \text { Undrained } \\
\text { shear } \\
\text { strength of } \\
\text { treated } \\
\text { kaolin } \\
\text { compacted } \\
\text { at } 2 \% \text { wet } \\
\text { of OMC } \\
(\mathrm{kPa})\end{array}$ & $\begin{array}{l}{ }^{\mathrm{e}} \text { Carbonation } \\
\text { strength } \\
\text { improvement } \\
\text { factor } \\
\text { relatively to } \\
\text { lime treated } \\
\text { kaolin }\end{array}$ \\
\hline [21] & $\begin{array}{l}\text { lean clay } \\
\text { soil }\end{array}$ & $\begin{array}{l}- \\
- \\
-\end{array}$ & $\begin{array}{l}15 \% \\
\mathrm{MgO} \\
15 \% \\
\mathrm{MgO} \\
15 \% \\
\mathrm{MgO}\end{array}$ & $\begin{array}{l}15 \mathrm{M} 18 \mathrm{AV} \\
15 \mathrm{M} 24 \mathrm{AV} \\
15 \mathrm{M} 32 \mathrm{AV}\end{array}$ & $\begin{array}{l}- \\
- \\
-\end{array}$ & $\begin{array}{l}250 \\
250 \\
250\end{array}$ & $\begin{array}{l}c 2500 \\
c 3500 \\
c 3250\end{array}$ & $\begin{array}{l}- \\
- \\
-\end{array}$ & $\begin{array}{l}10 \\
14 \\
13\end{array}$ \\
\hline
\end{tabular}

${ }^{a} \mathrm{CaO}$ equivalent calculated from actual $\mathrm{Ca}(\mathrm{OH})_{2}$ additions. ${ }^{\mathrm{b}}$ carbonated specimens were saturated with $\mathrm{HC}$ solution in triaxial cell set-up prior to UCS testing, UCS results based on three tests per mix. HC represents high carbon. ' UCS of carbonated MgO treated lean clay soil specimen. ${ }^{\mathrm{d} U C S}$ data taken directly from the authors report. ${ }^{\mathrm{e}}$ Determined by comparing the UCS of carbonated treated specimen to the equivalent noncarbonated treated specimen. Note: UCS represents unconfined compressive strength, L represents \% calcium hydroxide, AV represents \% air voids. $\mathrm{MgO}$ stands for magnesia. M represents \% magnesium oxide. 


\section{V.D. Implication for Carbon Capture}

Lime is used for a range of purposes for which it is uniquely suitable. The research presented in this paper addresses the carbon capture function that operates alongside the primary purpose that justifies its manufacture.

The control of air voids content in $\mathrm{Ca}(\mathrm{OH})_{2}$ treated clay promotes carbonation of calcium and offers potential for carbon capture in clay soil. Treated kaolin in the current study suggests, from volumetric and mass balance data, that approximately $5 \%-10 \%$ of $\mathrm{CaCO}_{3}$ has been produced, fixing carbon. This has been achieved as a result of carbonation of $4 \%-8 \% \mathrm{Ca}(\mathrm{OH})_{2}$ content in kaolin clay (previously presented in Section IV.B).

Lime is manufactured from natural deposits of limestone, which mostly is $\mathrm{CaCO}_{3}$. The production of lime generates $\mathrm{CO}_{2}$, which is mainly during the calcination stage as represented by Equation (6) [3]

$$
\mathrm{CaCO}_{3} \rightarrow \mathrm{CaO}+\mathrm{CO}_{2}
$$

Based on $\mathrm{CO}_{2}$ emission from calcination stage (Equation (6)), it can be estimated that the global $\mathrm{CO}_{2}$ emissions from lime production (for all purposes) of $350 \mathrm{Mty}^{-1}$ [28] is approximately $275 \mathrm{Mt} \mathrm{CO}_{2} \mathrm{y}^{-1}$ (Table A1, Appendix I). In view of current concerns about climate change due to increasing atmospheric $\mathrm{CO}_{2}$ concentrations, the use of $\mathrm{Ca}(\mathrm{OH})_{2}$ treated soil for carbon capture function alongside engineering function is an important consideration.

The design manual for roads and bridges [29] recommends a capping layer at locations where weak cohesive soil (with CBR of less than 15\%) is encountered as a subgrade of highway pavement. The capping layer is required between subgrade and sub-base to provide a suitably firm working platform for placement and compaction of sub-base. The capping layer acts as a structural layer in the long term and reduces the thickness of sub-base which otherwise would be required [27]. Lime stabilization of cohesive soil for the capping layer has attracted significant recommendation, particularly when it would be cheaper alternative to the use of granular material or if environmental benefits are considered [23], [27], [29]. Lime stabilizations have been widely used in capping layers construction of highway projects including the UK [27].

Generally, it has been found from the observations in lime stabilization of soil with high sulphate content that, too high air voids can promote the formation of ettringite or thaumasite, leading to heave problems [27]. Considering that high air voids content is required for the carbonation of lime treated soil, lime treatment of soil for carbonation should be handled with caution when dealing with sulphate bearing soils.

The current study suggests that a controlled air voids content of lime stabilized soil in road pavement capping may capture $\mathrm{CaCO}_{3}$ as carbon. By the design of lime treated soil, $\mathrm{CO}_{2}$ emissions due to lime production can be off-set to maximise carbon capture (Table 5). EuLA [3] estimated that $18 \%$ of total lime production is used for the construction sector based on lime functionality. Lime is used by four main areas of construction, which includes its use as a stabilizer for soil modification and stabilization, as a binder for production of sandlime bricks, fire resistance board and concrete. Lime is also used as a component of mortar and plasters, and as an anti-stripping agent in production of asphalt and tarmac for road construction [3]. It is considered that $25 \%$ of the construction lime is used for soil modification and stabilization, hence $4.5 \%$ of global lime used for soil modification and stabilization. Using a combined modification and carbonation technique proposed in the current study, a global carbon capture potential of approximately $11-12 \mathrm{MtCO}_{2}$ may be speculated for $4 \%-8 \% \mathrm{Ca}(\mathrm{OH})_{2}$ (by dry mass) addition, which is equivalent to $93 \%$ of the $\mathrm{CO}_{2}$ emissions associated with lime production for modification and stabilization (Table 5). The current study suggests that lime treated soil would recover up to $93 \%$ of the $\mathrm{CO}_{2}$ emissions associated with lime production, alongside providing additional engineering functions. 
TABLE 5 Global Carbon Capture Potential in Carbonation of Calcium Hydroxide $\left(\mathrm{Ca}(\mathrm{OH})_{2}\right)$ Treated Kaolin Clay

\begin{tabular}{lll}
\hline Description & Quantity of Quantity Notes \\
& lime content & \\
$(\%)$ &
\end{tabular}

\begin{tabular}{|c|c|c|c|}
\hline Global figures & & & \\
\hline Global lime production & & $350 \mathrm{Mt} \mathrm{y}^{-1}$ & USGS [28]- 2015 figures \\
\hline Global lime for construction & & ${ }^{\mathrm{a}} 63 \mathrm{Mt} \mathrm{y}^{-1}$ & $18 \%$ of total lime $[3]$ \\
\hline $\begin{array}{l}\text { Global lime for soil } \\
\text { modification and stabilization }\end{array}$ & & $16 \mathrm{Mt} \mathrm{y}^{-1}$ & $\begin{array}{l}25 \% \text { of constructions lime } \\
(4.5 \% \text { of total lime), based on } \\
\text { four areas of construction lime }\end{array}$ \\
\hline $\begin{array}{l}\text { Emission from global lime } \\
\text { production }\end{array}$ & & ${ }^{\mathrm{c}} 275 \mathrm{Mt} \mathrm{y}^{-1}$ & $\begin{array}{l}\text { Based on Stoichiometry in } \\
\text { Equation (6) }\end{array}$ \\
\hline $\begin{array}{l}\text { Global maximum carbon } \\
\text { capture potential }\end{array}$ & $\begin{array}{l}4 \% \mathrm{Ca}(\mathrm{OH})_{2} \\
6 \% \mathrm{Ca}(\mathrm{OH})_{2} \\
8 \% \mathrm{Ca}(\mathrm{OH})_{2}\end{array}$ & $\begin{array}{l}11.3 \mathrm{MtCO}_{2} \\
11.7 \mathrm{MtCO}_{2} \\
11.7 \mathrm{MtCO}_{2}\end{array}$ & $\begin{array}{l}\text { Based on carbonation of lime } \\
\text { for stabilization }\end{array}$ \\
\hline $\begin{array}{l}\text { Carbon capture potential based } \\
\text { on global emission from lime } \\
\text { production for modification and } \\
\text { stabilization }\end{array}$ & $\begin{array}{l}4 \% \mathrm{Ca}(\mathrm{OH})_{2} \\
6 \% \mathrm{Ca}(\mathrm{OH})_{2} \\
8 \% \mathrm{Ca}(\mathrm{OH})_{2}\end{array}$ & $\begin{array}{l}90 \% \mathrm{CO}_{2} \\
93 \% \mathrm{CO}_{2} \\
93 \% \mathrm{CO}_{2}\end{array}$ & $\begin{array}{l}\text { carbon capture potential based } \\
\text { on degree of carbonation of } \\
\mathrm{Ca}(\mathrm{OH})_{2} \text { in modified kaolin in } \\
\text { the current study }\end{array}$ \\
\hline
\end{tabular}

Note $\mathrm{Mty}^{-1}$ represents million tonnes per year, ${ }^{\mathrm{a}}$ Estimates based on $18 \%$ lime for construction function [3]. ${ }^{\mathrm{c}}$ Estimates based on lime production $\mathrm{CO}_{2}$ emission from stoichiometry in Equation (6).

\section{CONCLUSIONS}

This paper has focused on the potential of combined carbon capture and strength improvement in lime treated kaolin. The important conclusions drawn are:

- Carbonation of lime treated kaolin has shown the potential for $\mathrm{CaCO}_{3}$ formation. In the current study, carbonation of $8 \% \mathrm{Ca}(\mathrm{OH})_{2}$ with $10 \%$ air voids treated kaolin specimen has resulted in the formation of up to $10 \pm 0.15 \% \mathrm{CaCO}_{3}$ content based on TGA.

- Combined modification and carbonation of treated kaolin clay could achieve strength improvement. Based on 7 days cured specimens, a carbonated treated kaolin at a combination of $6 \% \mathrm{Ca}(\mathrm{OH})_{2}$ and $10 \%$ air voids resulted in $65 \%$ increase in strength (from $170 \mathrm{kPa}$ to $280 \mathrm{kPa}$ ) when compared with the strength of corresponding non-carbonated treated kaolin specimen. This strength is equivalent to CBR value of $29 \%$. This CBR value is greater than the value of $15 \%$ which is the minimum CBR required for a stabilized capping layer [23], [29]. Based on strength requirements, the strength of carbonated treated kaolin in the current study is sufficient for use as a stabilized capping layer.

- A control of air voids content in lime treated kaolin could produce desired carbonation, and hence the optimum combined carbon capture and strength improvement. In the current study $10 \%$ air voids content achieved the combined desired effect.

- In the current study, a combined modification and carbonation technique has shown the potential to offset up to $93 \%$ of the $\mathrm{CO}_{2}$ released from lime production for stabilization, alongside the compressive strength improvement of up to $280 \mathrm{kPa}$ (equivalent to CBR value of $29 \%$ ). This was achieved in carbonated treated kaolin at combination of $6 \% \mathrm{Ca}(\mathrm{OH})_{2}$ and $10 \%$ air voids. This carbonated lime treated kaolin could be used as a stabilized capping layer in road pavement.

- Ultimately, if combined modification and carbonation is applied to treated kaolin, it has the potential to mitigate climate change alongside ground improvement. Although the improvement in carbonated treated kaolin at combination of $6 \% \mathrm{Ca}(\mathrm{OH})_{2}$ and $10 \%$ air voids has proven to be successful, it would be useful to carry out further studies on combined modification and carbonation studies involving swelling clays such as bentonite.

\section{CONFLICT OF INTEREST}

The authors declare that there is no conflict of interest

\section{ACKNOWLEDGEMENTS}

The authors wish to thank Petroleum Technology Development Fund (PTDF) Nigeria for a PhD scholarship to the first author. Special thanks to Prof. Stephanie Glendinning and Prof. David Manning for their guidance during the research at Newcastle University, UK. Many thanks to Stuart Patterson and Fred Beadle for support in the Lab., Bernard Bowler for TG-DSC-QMS analysis, and Philip Green for CEC analysis (Newcastle 
University, UK). The supply of lime by Buxton Lime Industries Ltd is gratefully acknowledged.

\section{REFERENCES}

[1] F. G. Bell, "Lime stabilization of clay minerals and soils," Engineering geology, vol. 42, no. 4, pp. 223-237, Jan. 1996

[2] C. D. F. Rogers, S. Glendinning, and T. E. J. Roff, (1997) "Lime modification of clay soils for construction expediency," Proceedings of the Institution of Civil Engineers-Geotechnical Engineering, Oct. 1997, vol. 125, no. 4, pp. 242-249,.

[3] M. Stork, W. Meindertsma, M. Overgaag, M. Neelis, "A competitive and efficient lime industry- cornerstone for a sustainable Europe," The European Lime Association, Brussels Belgium, Technical report, www.eula.eu, 2014.

[4] T. F. Stocker, D. Qin, G. K. Plattner, M. Tignor, S. K. Allen, J. Boschung, A. Nauels, Y. Xia, V. Bex, and P. M., Midgley, (eds.). "Climate change 2013: The physical science basis. Contribution of working group I to the fifth assessment report of the intergovernmental panel on climate change," Cambridge University Press, Cambridge, United Kingdom and New York, NY, USA, Technical Report, pp. 1-1535, 2013.

[5] C. D. Butler, "Sounding the alarm: health in the anthropocene," International Journal of Environmental Research and Public Health, vol. 13, no. 665, pp. 1-15, June, 2016.

[6] R. J. Dawson, D. Thompson, D. Johns, S. Gosling, L. Chapman, G. Darch, G. Watson, W. Powrie, S. Bell, K. Paulson, P. Hughes, and R. Wood, "UK climate change risk assessment evidence report: Chapter 4, infrastructure," Report prepared for the adaptation sub-committee of the committee on climate change, London, Technical Report, pp. 1-110, 2016.

[7] D. A. Manning, and P. Renforth, "Passive sequestration of atmospheric $\mathrm{CO}_{2}$ through coupled plant-mineral reactions in urban soils," Environmental science \& technology, vol. 47, pp.135-141, May, 2013.

[8] C. L. Washbourne, E. Lopez-Capel, P. Renforth, P. L. Ascough, and D. A. Manning, "Rapid removal of atmospheric $\mathrm{CO}_{2}$ by urban soils," Environmental science \& technology, vol. 49, no. 9, pp. 5434-5440, April, 2015.

[9] C. Jung, and A. Bobet, "Post-construction evaluation of lime-treated soils," Joint Transportation Research Program, Indiana Department of Transportation and School of Civil Engineering Purdue University, Technical Report FHWA/IN/JTRP-2007/25, SPR-3007, May, 2008.

[10] D.T. Davidson, and R.L. Handy, "Lime and lime-pozzolan stabilization," Highway Engineering Handbook, pp. 21-100, 1960.

[11] Y. A. Iorliam, "Carbon capture potential in modified soil," PhD. Thesis, School of Engineering, Newcastle University, Newcastle upon Tyne, United Kingdom, Nov. 2018.

[12] Hydraulically bound and stabilized materials for civil engineering purposes Part 2: Sample preparation and testing of materials during and after treatment. BS 1924-2, British Standards Institution, Milton Keynes, 2018

[13] D. N. Little, "Evaluation of structural properties of lime stabilized soils and aggregates, mixture design and testing protocol for lime stabilized soils," National Lime Association report, vol. 1, (http://www.lime.org/soil3.PDF), 1999.

[14] Methods of test for soils for civil engineering purposes Part 6: Consolidation and permeability tests in hydraulic cells and with pore pressure measurement, BS 1377-6, British Standards Institution, Milton Keynes, 1990.

[15] Soil quality. Chemical methods. Determination of specific electrical conductivity, BS 7755-3.4, British Standards Institution, Milton Keynes, 1995.

[16] Soil quality, Determination of carbonate content, volumetric method, BS EN ISO 10693: British Standards Institution, Milton Keynes, 2014.

[17] W. Han, M. Zheng, A. Banerjee, Y. Z. Luo, L. Shen and Khursheed, A., "Quantitative material analysis using secondary electron energy spectromicroscopy". Scientific reports, vol. 10, no. 1., pp.1-14, 2020.

[18] J. E. R, Grim, and J. L. Eades, "A quick test to determine lime requirements of lime stabilisation," Highway Research Record, issue no. 139 , pp. 61-72, 1966.

[19] Y. Yi, M. Liska, C. Unluer and A. Al-Tabbaa, "Carbonating magnesia for soil stabilization," Canadian Geotechnical Journal, vol. 50, no.8, pp. 899-905, June 2013.

[20] F. Matsushita, Y. Aono, and S. Shibata, Carbonation degree of autoclaved aerated concrete. Cement and concrete research, vol. 30, no. 11, pp.1741-1745, Nov. 2000.

[21] Y. Yi, K. Lu, S. Liu, and A. Al-Tabbaa, "Property changes of reactive magnesia-stabilized soil subjected to forced carbonation," Canadian Geotechnical Journal, vol. 53, no. 2, pp.314-325, August, 2015.

[22] G. E. Barnes, Soil mechanics: principles and practice, $3^{\text {rd }}$ ed. Great Britain: Palgrave macmillan, 2010.

[23] Manual of contract documents for highway works, Specification for Highway Works, vol. 1, HMSO, London, amended February, 2016.

[24] P. De Silva, L. Bucea, D. R. Moorehead, and V. Sirivivatnanon, "Carbonate binders: reaction kinetics, strength and microstructure," Cement and Concrete Composites, vol. 28, no. 7, pp.613-620, June, 2006.

[25] D. I. Boardman, S. Glendinning, and C. D. F. Rogers, "Development of stabilisation and solidification in lime-clay mixes," Geotechnique, 51(6), pp. 533-543, Jan. 2001.

[26] J. Danistan, and C. Vipulanandan, "Correlation between California Bearing Ratio (CBR) and soil parameters," "In: CIGMAT-2010 conference and exhibition, 2010. Available from: http://cigmat.cive.uh.edu/, pp. 1-2.

[27] P. T. Sherwood, "Soil stabilisation with cement and lime - state of the art review," Transport Research Laboratory, Department of Transport, HMSO publications, ISBN 0-11551171-7, London, 1993.

[28] U.S. Geological Survey, Mineral commodity summaries 2016, U.S. Geological Survey, 202 p., http://dx.doi.org/10.3133/70140094, Washington, 2016.

[29] Design Manual for Roads and Bridges, Treatment of fill and capping materials using either lime or cement or both, DMRB Vol 4, Section 1, Part 6 (DMRB 4.1.6), Ha 74, HMSO, London, May, 2007. 


\section{APPENDIX I: DETERMINATION OF GLOBAL $\mathrm{CO}_{2}$ EMISSIONS FROM LIME PRODUCTION}

TABLE A1 Determination of Global $\mathrm{Co}_{2}$ Emissions from Lime Production using Annual Lime Production, Based on the Global $\mathrm{Co}_{2}$ Emissions from Cement Production.

\begin{tabular}{|l|l|l|l|l|l|}
\hline Property & Year & $\begin{array}{l}\text { Clinker } \\
\text { (metric } \\
\text { tonnes) }\end{array}$ & $\begin{array}{l}\text { Lime } \\
\text { calcium } \\
\text { oxide } \\
\text { content, in } \\
\text { metric } \\
\text { tonnes })\end{array}$ & $\begin{array}{l}{ }^{\mathrm{c}} \text { Limestone } \\
\left(\mathrm{CaCO}_{3}\right)\end{array}$ & $\begin{array}{l}{ }^{\mathrm{d}} \text { Annual } \\
\mathrm{CO}_{2} \text { emission } \\
\text { contribution }\end{array}$ \\
\hline $\begin{array}{l}\text { Cement } \\
\text { production }\end{array}$ & 2015 & ${ }^{\mathrm{a}} 3,600 \times 10^{6}$ & $\begin{array}{l}\mathrm{b} 2,325.6 \times \\
10^{6}\end{array}$ & $4152.9 \times 10^{6}$ & ${ }^{\mathrm{e}} 1827 \times 10^{6}$ \\
\hline $\begin{array}{l}\text { Lime } \\
\text { production }\end{array}$ & 2015 & NA & ${ }^{\mathrm{a}} 350 \times 10^{6}$ & $625 \times 10^{6}$ & ${ }^{\mathrm{f}} 275 \times 10^{6}$ \\
\hline
\end{tabular}

NA $=$ Not applicable

${ }^{a}$ Values based on U.S. Geological Survey, Mineral Commodity Summaries, January 2016 [26].

${ }^{\mathrm{b}}$ Mass determined based on lime content in clinker equal to $64.6 \%$ clinker mass [4].

${ }^{c} \mathrm{CaCO} 3$ determined based on Equation $\mathrm{A} 1: \mathrm{CaCO}_{3} \rightarrow \mathrm{CaO}+\mathrm{CO}_{2}$ Relative molar mass $(\mathrm{g})$ 100 $56 \quad 44$

${ }^{\mathrm{d}}$ Emissions due to calcination (processing), excluding emission due to fuel combustion.

${ }^{\mathrm{e}}$ Based on Equation A1, the amount of $2,325.6 \times 10^{6}$ metric tonnes of calcium oxide in cement production could produce $1827.25 \times 10^{6}$ $\mathrm{CO}_{2}$ emissions to the atmosphere. This represents global $\mathrm{CO}_{2}$ emissions of $4 \% \mathrm{CO}_{2} / \mathrm{yr}[4]$.

${ }^{\mathrm{f}}$ Therefore, based on global lime (calcium oxide) production in 2015 data, $350 \times 10^{6}$ metric tonnes of lime could produce $275 \times 10^{6}$ $\mathrm{CO}_{2} / \mathrm{yr}$ emissions to the atmosphere.

\section{AUTHOR PROFILE}

Dr. Amos Yala Iorliam is Senior Lecturer at the Department of Civil Engineering, Joseph Sarwuan Tarka University Makurdi (JOSTUM), Nigeria (formerly Federal University of Agriculture Makurdi) from 2019 to date. He was Lecturer I from 2013 to 2019, and Lecturer II from 2010 to 2013 all at the Department of Civil Engineering, JOSTUM, Nigeria. His research interests lie mainly in carbon capture in soils, and soil improvement using waste materials for application in pavement. Dr. Iorliam offers lectures mainly in Geotechnical Engineering, Soil Mechanics and Engineering Geology to Undergraduate and Postgraduate students in the same University. Also, he is involved in research and community development. He is a Registered Engineer with Council for the Regulation of Engineering Practice in Nigeria (COREN) since 2019. He obtained PhD in Civil Engineering (Geotechnical Engineering option) from Newcastle University, Newcastle upon Tyne, United Kingdom in 2018. Also, he acquired MSc and B.Eng. Civil Engineering from University of Ibadan, Nigeria (2010) and Federal University of Agriculture Makurdi, Nigeria (2004) respectively. Dr. Iorliam has published several papers related to soil improvement using waste materials for road pavement.

Engr. Moses Msuega Ufe is Lecturer I at the Department of Civil Engineering, Joseph Sarwuan Tarka University Makurdi (JOSTUM), Nigeria (formerly Federal University of Agriculture Makurdi) from 2019 to date. He was Lecturer II from 2016 to 2019, and Graduate Assistant from 2012 to 2016 all at the Department of Civil Engineering, JOSTUM, Nigeria. His research interest is in Structural Engineering Modelling and Structural Dynamics. He obtained M.Sc (Structural Engineering) in 2016 at the Newcastle University, Newcastle upon Tyne, United Kingdom, and B.Eng. (Civil Engineering) at the Federal University of Agriculture Makurdi in 2010. He has lectured courses in Advanced Structural engineering, and supervised several Undergraduate Final Year Students' Projects. He is currently undergoing a $\mathrm{PhD}$ (Structural Engineering) at the Federal University of Technology Minna, Nigeria. His publication is on structural modelling of engineering structures.

Benedict Anum is Lecturer II at the Department of Civil Engineering, Joseph Sarwuan Tarka University Makurdi (JOSTUM), Nigeria (formerly Federal University of Agriculture Makurdi) from 2019 to date. His research interest is in structural optimization and structural dynamics/reliability. He got M.Eng. (Structural engineering) in 2019 at the Federal University of Technology Minna, Nigeria, and B.Eng. (Civil Engineering) in 2013 at Federal University of Agriculture Makurdi. Benedict offer lectures mainly in Structural Mechanics, strength of Materials and Structural analysis. Benedict is a PhD researcher (Structural Engineering) at the Federal University of Technology Minna, Nigeria. His publications are related to design optimization of civil engineering structures. 